\title{
POTRET STUNTING PADA ANAK PENDIDIKAN ANAK USIA DINI
}

\author{
Jojor Silaban \\ Prodi D-III Keperawatan Dairi Poltekkes Kemenkes Medan \\ Jl. Medan Km.4,5 Panji Bako Sidikalang-Dairi e-mail: silaban.jojor473@gmail.com
}

\begin{abstract}
Abstrak
Masalah kurang gizi kronis dalam bentuk anak stunting belum menunjukkan perkembangan yang menggembirakan. Prevalensi stunting secara nasional tahun 2013 adalah 37,2 persen. Hasil penelitian Silaban tahun 2015 di Kecamatan Parbuluan menunjukkan ada 31,84\% anak Pendidikan Anak Usia Dini (PAUD) dengan keadaan stunting. Jenis penelitian ini adalah survei deskriptif, untuk menggambarkan potret stunting di Kabupaten Dairi tahun 2018 dengan jumlah sampel 1193 orang. Hasil Penelitian menunjukkan pada anak PAUD terdapat stunting $31,85 \%$ dan severe stunting sebesar $1,17 \%$, apabila diakumulasikan maka anak stunting seluruhnya ada 33,03 \%. Anak yang mengalami stunting lebih banyak terjadi pada jenis kelamin perempuan sebesar 58,6 \%, keluarga dengan penghasilan kurang yaitu sebesar 57,6 \%, berat badan lahir normal sebesar 72,1\% dan hanya 27,9\% yang lahir dengan berat badan lahir rendah, jarak kelahiran dengan adiknya dekat sebesar 53,6 \%, dan mengalami kejadian infeksi dengan kategori jarang sebesar 58,4\%.
\end{abstract}

Kata kunci : stunting, potret stunting

\begin{abstract}
The problem of chronic malnutrition in the form of stunting children has not shown encouraging developments. The prevalence of stunting nationally in 2013 was 37.2 percent. The results of Silaban's 2015 research in Parbuluan District showed that there were $31.84 \%$ of Early Childhood Education (PAUD) children with stunting. This type of research is a descriptive survey, to describe the portrait of stunting in Dairi Regency in 2018 with a sample of 1193 people. The results showed that in PAUD children there were $31.85 \%$ stunting and $1.17 \%$ severe stunting, if accumulated, the total stunting children were $33.03 \%$. Children who experience stunting are more common in the female sex by 58.6\%, families with less income by $57.6 \%$, normal birth weight by $72.1 \%$ and only $27.9 \%$ born with low birth weight. , the distance between births and siblings is close by 53.6\%, and the incidence of infection in the rare category is $58.4 \%$.

Keywords: stunting, stunting portrait
\end{abstract}




\section{Pendahuluan}

Berbicara tentang gizi kurang, fokus perhatian akan tertuju pada anak terutama balita. Masa balita merupakan masa pertumbuhan dan perkembangan yang sangat pesat, sehingga kerap diistilahkan sebagai periode emas sekaligus periode kritis. Periode emas dapat diwujudkan apabila pada masa ini memperoleh asupan gizi yang sangat sesuai untuk tumbuh kembang optimal, sebaliknya apabila pada masa ini tidak memperoleh makanan sesuai kebutuhan gizinya maka periode emas berubah menjadi periode kritis yang akan mengganggu tumbuh kembangnya. ${ }^{1}$

Manurut Manaray \& Solomons stunting adalah keadaan tubuh yang pendek dan sangat pendek melampaui deficit -2 SD di bawah median panjang atau tinggi badan. ${ }^{2}$ Stunting merupakan masalah kesehatan masyarakat yang mempunyai dampak sangat besar terhadap kualitas hidup manusia tetapi masing sering dianggap bukan masalah kesehatan baik oleh masyarakat awam maupun tenaga kesehatan, sehingga masalah penanganan stunting kurang mendapat perhatian. Dampak stunting antara lain adalah gangguan tumbuh kembang secara fisik, mental, sosial dan intelektual yang sifatnya menetap dan terus dibawa sampai anak menjadi dewasa. Anak-anak pendek menghadapi kemungkinan yang lebih besar untuk tumbuh menjadi orang dewasa yang kurang berpendidikan, miskin, kurang sehat dan lebih rentan terhadap penyakit tidak menular. ${ }^{3}$ Studi longitudinal di Guatemala menunjukkan bahwa anak yang pendek memiliki tingkat kecerdasan yang lebih rendah. Produktivitas orang dewasa yang memiliki riwayat gizi kurang pada usia 0 - 2 tahun juga kurang. Dari studi ini ditarik kesimpulan bahwa tinggi anak merupakan prediktor terbaik kualitas sumber daya manusia. $^{4,5}$

Prevalensi pendek secara nasional tahun 2013 (35,6\%) dan 2007 (36,8\%). Pada tahun 2013 prevalensi sangat pendek menunjukkan penurunan, dari 18,8 persen tahun 2007 dan 18,5 persen tahun 2010. Prevalensi pendek meningkat dari 18,0 persen pada tahun 2007 
menjadi 19,2 persen pada tahun 2013. Terdapat dua puluh provinsi di atas prevalensi nasional, salah satunya adalah propinsi Sumatera Utara menempati urutan ke delapan prevalensi tertinggi anak stunting di Indonesia. ${ }^{6,7}$

Hasil penelusuran Pustaka menunjukan bahwa anak dengan keadaan stunting lebih banyak terjadi pada anaklaki-laki, pendapatan keluarga rendah, berat badan lahir rendah, jarak kelahiran yang dekat, serta riwayat infeksi yang sering di derita anak. Pendapatan yang rendah mengakibatkan kemampuan keluarga dalam pengadaan bahan makanan yang berkualitas menjadi rendah. Berdasarkan penelitian sebagian besar anak-anak dengan stunting mengonsumsi makanan yang berada di bawah ketentuan rekomendasi kadar gizi, berasal dari keluarga miskin dengan jumlah keluarga banyak, bertempat tinggal di wilayah pinggiran kota dan komunitas pedesaan. ${ }^{8}$ Berat badan lahir rendah adalah berat badan bayi ketika lahir $<2500$ gram berhubungan secara signifikan terhadap stunting. Hasil penelitian Fitri dari Analisis Hasil Riskesdas 2010 di Sumatera menyatakan bahwa bayi dengan BBLR memiliki risiko stunting 1,7 kali dibanding bayi yang lahir dengan berat badan normal. ${ }^{7}$ Penyakit infeksi berulang yang sering terjadi pada anak yaitu infeksi saluran pernafasan dan diare berperan dalam kejadian stunting. Anak yang sering mengalami penyakit infeksi, secara langsung akan berisiko mengalami status gizi buruk. ${ }^{8}$ Jarak kelahiran yang terlalu dekat mengakibatkan anak tidak mendapat pengasuhan yang adekuat terutama dalam pengasuhan pemberian makan di mana apabila terjadi kehamilan di bawah dua tahun, ibu akan menghentikan pemberian ASI kepada anak, ibu juga membagi perhatiannya terhadap anak dan janin dalam kandungan sehingga kemungkinan pengasuhan pemberian makan kepada anak menjadi tidak adekuat. ${ }^{9}$

Data yang valid mengenai keadaan stunting di Kabupaten Dairi sampai saat ini belum ada. Namun hasil penelitian Silaban tahun 2015 di Kecamatan Parbuluan menunjukkan ada 31,84\% anak Pendidikan Anak Usia Dini (PAUD) dengan keadaan stunting. ${ }^{10}$ Berdasarkan 
uraian data-data di atas, peneliti merasa tertarik untuk meneliti potret stunting pada anak PAUD di Kabupaten Dairi tahun 2018. Tujuan penelitian ini adalah untuk menggambarkan potret stunting pada anak PAUD di Kabupaten Dairi tahun 2018.

\section{Metode Penelitian}

Penelitian ini adalah penelitian survei deskriptif untuk menggambarkan karakteristik anak PAUD yang mengalami stunting di Kabupaten Dairi. Dilakukan padabulan Oktober sampai Desember tahun 2018. Populasi penelitian ini adalah seluruh anak PAUD di Kabupaten Dairi sejumlah 4773 orang. Penarikan sampel dilakukan secara purposive sampling dengan jumlah $25 \%$ dari jumlah populasi, maka jumlah sampel seluruhnya adalah 1.193 orang. Responden adalah ibu dari anak PAUD dan subjek penelitian adalah anak PAUD. Pengukuran tinggi badan dilakukan oleh peneliti menggunakan microtoise. Data tentang penghasilan orang tua, berat badan lahir, riwayat infeksi, jarak kelahiran dan jenis kelamin anak didapatkan melalui pengisian kuisioner oleh responden.

\section{Hasil Penelitian}

Hasil penelitian menunjukkan anak PAUD di seluruh Kabupaten Dairi yang mengalami stunting sebesar $31,85 \%$ dan severe stunting sebesar $1,17 \%$. Lebih jelasnya dapat dilihat pada table di bawah ini.

Tabel 1 Distribusi Karakteristik Anak Pendidikan Anak Usia Dini berdasarkan Tinggi Badan di Kabupaten Dairi tahun 2018

\begin{tabular}{clcc}
\hline No & \multicolumn{1}{c}{ Tinggi Badan } & $\begin{array}{c}\text { f } \\
\text { orang }\end{array}$ & \% \\
\hline 1. & Normal & 799 & 66,87 \\
2. & Pendek/stunting & 380 & 31,85 \\
3. & Sangat Pendek/severe stunting & 14 & 1,17 \\
& Jumlah & 1193 & 100 \\
\hline
\end{tabular}

Tabel 1 menunjukkan bahwa anak yang mengalami stunting dan severe stunting sebesar 31,85\% dan 1,17\%, apabila diakumulasikan maka anak yang bermasalah dalam hal tinggi badan seluruhnya ada 33,03\%. Selanjutnya peneliti mendistribusikan anak dengan keadaan stunting di setiap kecamatan seperti terlihat pada table berikut. 
Tabel 2 Distribusi Karakteristik Anak Pendidikan Anak Usia Dini berdasarkan Tinggi Badan pada Setiap Kecamatan Kabupaten Dairi tahun 2018

\begin{tabular}{|c|c|c|c|c|c|c|c|}
\hline \multirow[t]{2}{*}{ No } & \multirow[t]{2}{*}{ Kecamatan } & \multicolumn{2}{|c|}{ TB Normal } & \multicolumn{2}{|c|}{ Stunting } & \multicolumn{2}{|c|}{ Severe Stunting } \\
\hline & & $\mathbf{F}$ & $\%$ & f & $\%$ & f & $\%$ \\
\hline 1. & Berampu & 12 & 60,0 & 7 & 35,0 & 1 & 5,0 \\
\hline 2 & Gunung Sitember & 19 & 67,9 & 9 & 32,1 & 0 & 0 \\
\hline $\mathbf{3}$ & Lae Parira & 23 & 65,7 & 10 & 28,6 & 2 & 5,7 \\
\hline 4 & Parbuluan & 59 & 63,4 & 34 & 36,6 & 0 & 0 \\
\hline 5 & Pegagan Hilir & 36 & 65,5 & 17 & 30,9 & 2 & 3,6 \\
\hline 6 & Sidikalang & 221 & 69,3 & 98 & 30,7 & 0 & 0 \\
\hline 7 & Siempat Nempu & 52 & 65,8 & 27 & 34,2 & 0 & 0 \\
\hline 8 & Siempat Nempu Hilir & 39 & 66,1 & 18 & 30,5 & 2 & 3,4 \\
\hline 9 & Siempat Nempu Hulu & 40 & 63,5 & 22 & 34,92 & 1 & 1,59 \\
\hline 10 & Silahi Sabungan & 11 & 68,8 & 4 & 25,0 & 1 & 6,3 \\
\hline 11 & Silima Pungga-Pungga & 24 & 66,7 & 11 & 30,6 & 1 & 2,8 \\
\hline 12 & Sitinjo & 21 & 58,3 & 13 & 36,1 & 2 & 5,6 \\
\hline 13 & Sumbul & 105 & 65,2 & 56 & 34,8 & 0 & 0 \\
\hline 14 & Tanah Pinem & 70 & 72,2 & 25 & 24,7 & 2 & 3,1 \\
\hline 15 & Tigalingga & 66 & 68,0 & 31 & 32,0 & 0 & 0 \\
\hline & Jumlah & 799 & 66,87 & 380 & 31,85 & 14 & 1,17 \\
\hline
\end{tabular}

BerdasarkanTabel 2 dapat dilihat anak dengan keadaan stunting dan severe stunting maka Kecamatan Sitinjo menduduki urutan pertama dengan jumlah 41,66\%, urutan kedua Kecamatan Berampu 40\% dan urutan ketiga Kecamatan Parbuluan 36,55\%.

Karakteristik atau gambaran anak PAUD yang mengalami stunting meliputi jenis kelamin, penghasilan orang tua, berat badan lahir, jarak kelahiran dan Riwayat infeksi dijelaskan pada table tabel di bawah ini.

Tabel 3 Distribusi Stunting Anak Pendidikan Anak Usia Dini berdasarkan Jenis Kelamin, Penghasilan Orang Tua, Berat Badan Lahir, Jarak Lahir dan Kejadian Infeksi di Kabupaten Dairi tahun 2018

\begin{tabular}{|c|c|c|c|}
\hline No & Karakteristik & $\begin{array}{c}F \\
\text { Orang }\end{array}$ & $\%$ \\
\hline \multicolumn{4}{|c|}{ Jenis Kelamin } \\
\hline 1. & Laki-Laki & 163 & 41,4 \\
\hline 2. & Perempuan & 231 & 58,6 \\
\hline & Jumlah & 394 & 100,0 \\
\hline \multicolumn{4}{|c|}{ Penghasilan Orang Tua } \\
\hline 1. & Kurang & 227 & 57,6 \\
\hline 2. & Cukup & 167 & 42,4 \\
\hline & Jumlah & 394 & 100,0 \\
\hline \multicolumn{4}{|c|}{ Berat Badan Lahir } \\
\hline 1. & Normal & 284 & 72,1 \\
\hline 2. & BBLR & 110 & 27,9 \\
\hline
\end{tabular}




\begin{tabular}{|c|c|c|c|}
\hline & Jumlah & 394 & 100,0 \\
\hline \multicolumn{4}{|c|}{ Jarak Lahir } \\
\hline 1. & Normal & 166 & 42,1 \\
\hline 2. & Dekat & 211 & 53,6 \\
\hline 3. & Sangat Dekat & 17 & 4,3 \\
\hline & Jumlah & 394 & 100,0 \\
\hline \multicolumn{4}{|c|}{ Kejadian Infeksi } \\
\hline 1. & Jarang & 230 & 58,4 \\
\hline 2. & Sering & 164 & 41,6 \\
\hline & Jumlah & 394 & 100,0 \\
\hline
\end{tabular}

Tabel 3 menunjukkan bahwa anak yang mengalami stunting lebih banyak terjadi pada jenis kelamin perempuan sebesar 58,6\%, keluarga dengan penghasilan kurang 57,6 \%, berat badan lahir normal sebesar 72,1\% dan hanya 27,9 \% yang lahir dengan berat badan lahir rendah, mayoritas jarak kelahiran dengan adiknya dekat sebesar 53,6 \%, mengalami kejadian infeksi dengan kategori jarang sebesar 58,4\%.

\section{Pembahasan}

Hasil penelitian menunjukkan bahwa anak yang mengalami stunting lebih banyak terjadi pada jenis kelamin perempuan sebesar 58,6 \% sedangkan pada laki-laki sebesar 41,4\%. Menurut UNICEF dalam BAPPENAS (2011), faktor langsung yang berhubungan dengan stunting yaitu karakteristik anak berupa jenis kelamin laki-laki, berat badan lahir rendah, konsumsi makanan berupa asupan energi rendah dan asupan protein rendah, yaitu status kesehatan penyakit infeksi ISPA dan diare. ${ }^{11}$ Hal ini tidak sesuai dengan hasil penelitian yang menunjukkan perempuan lebih banyak dari pada laki-laki, hal ini kemungkinan disebabkan pada dasarnya jumlah populasi jauh lebih banyak perempuan dari pada laki-laki.

Status ekonomi keluarga akan memengaruhi kemampuan pemenuhan gizi keluarga dan kemampuan mendapatkan layanan kesehatan. Anak pada keluarga dengan status ekonomi rendah lebih berisiko mengalami stunting karena kemampuan pemenuhan gizi yang rendah, meningkatkan risiko terjadinya malnutrisi. ${ }^{12}$ Hasil penelitian ini sesuai dengan hasil penelitian di Bangladesh tahun 2011, dan juga di Brazil tahun 2008 yang menyatakan bahwa 
status sosial ekonomi yang rendah merupakan faktor risiko kejadian stunting pada anak balita. ${ }^{13,14}$

Jarak kelahiran yang terlalu dekat, akan mengakibatkan usia penyapihan dini. Pada masa bayi 0-6 bulan ASI menjadi makanan utama, jika terjadi kehamilan berikut pada usia bayi di bawah 6 bulan, maka pemberian ASI akan dihentikan, atau apabila pemberian ASI tetap dilanjutkan, kandungan nutrisi tidak mencukupi untuk kebutuhan bayi. ${ }^{15,16}$ Hasil penelitian ini menunjukkan bahwa anak stunting mayoritas jarak kelahiran dengan adiknya dekat sebesar 53,6 \%. Penelitian ini sesuai dengan penelitian Arifin dkk pada balita di Purwakarta bahwa faktor yang paling berhubungan dengan kejadian stunting adalah jarak kelahiran. ${ }^{17}$

Hasil penelitian ini menunjukkan bahwa anak stunting yang lahir dengan berat badan lahir normal sebesar 72,1 \% dan hanya 27,9 \% yang lahir dengan berat badan lahir rendah. Berdasarkan wawancara mendalam kepada responden mengatakan bahwa berat badan lahir anak banyak berupa prakiraan saja karena banyak ibu yang sudah lupa berat badan anak waktu lahir. Hal ini kemungkinan yang menyebabkan gambaran berat badan lahir mayoritas normal. Penelitian ini tidak sesuai dengan penelitian Rahayu dan Sofyaningsih tahun 2011 bahwa bayi yang lahir dengan BBLR mempunyai risiko untuk mengalami stunting pada usia 6-12 bulan sebesar 3,6 kali dibandingkan dengan bayi yang lahir dengan berat badan normal. $^{18}$

Hasil penelitian menunjukkan bahwa anak stunting mayoritas mengalami kejadian infeksi dengan kategori jarang sebesar 58,4\%. Hasil penelitian ini sesuai dengan penelitian yang dilakukan di Kecamatan Semarang Timur yang menunjukkan bahwa riwayat penyakit infeksi merupakan faktor risiko kejadian Stunting yang tidak bermakna. ${ }^{15}$

\section{Kesimpulan dan Saran}


Hasil penelitian menunjukkan anak PAUD dengan stunting seluruhnya ada 33,03\%, Kecamatan Sitinjo menduduki posisi tertinggi dengan jumlah 41,66\% dan terendah di Kecamatan Tanah Pinem sebesar 27,83\%. Anak yang mengalami stunting lebih banyak terjadi pada jenis kelamin perempuan sebesar 58,6 \%, keluarga dengan penghasilan kurang yaitu sebesar 57,6 \%, berat badan lahir normal sebesar 72,1\%, jarak kelahiran dekat sebesar $53,6 \%$, dan mengalami kejadian infeksi dengan kategori jarang sebesar 58,4\%. Perlu dilakukan penelitian lebih lanjut mengenai Stunting pada anak PAUD dengan variabel yang lebih luas.

\section{Kata Pengantar}

Penelitian ini dilaksanakan dengan subsidi biaya dari Akademi Keperawatan Pemerintah Kabupaten Dairi. Peneliti menyampaikan terimakasih kepada Direktur Akper Pem. Kab Dairi Bapak Roberth Harnat Silalahi, SKM dan rekan rekan dosen Risdiana Melinda Naibaho, Herlina Evi Yanti Manik, Rugun Toianur Lingga beserta mahasiswa yang berkenaan membantu sebagai enumerator. Terimakasih juga disampaikan kepada seluruh pengelola PAUD yang menjadi tempat penelitian ini dilaksanakan. Secara khusus terimakasih kepada suami tercinta telah menjadi driver yang baik selama proses pengumpulan data.

\section{DAFTAR PUSTAKA}

1. Depkes R. Pencegahan dan penanggulangan gizi buruk. Jakarta : Departemen Kesehatan Republik Indonesia; 2005.

2. Solomons M, Oxford. Gizi dan kesehatan masyarakat, Terjemahan Public Health Nutrition. 2009.

3. UNICEF. The State Of the World's Children. 1998.

4. Nurlinda A. Gizi dalam siklus daur kehidupan seri baduta (untuk anak 1-2 tahun). Edisi I edn. Yogyakarta : Penerbit ANDI; 2013. hlm. 31-33.

5. Victoria. Data anak-anak PBB 2008,ukur DHS 2007. Jakarta : 1992.

6. Indonesia, KKR. Riset kesehatan dasar 2013. Jakarta : Kemenkes RI; 2013.

7. Fitri. Beratlahir sebagai faktor dominan terjadinya stunting pada balita (12-59 bulan) di Sumatera (Analisis Riskesdas 2010). [Tesis] Depok : Universitas Indonesia; 2012.

8. Paath EF, Rumdasih Y, Heryati. Gizi dalam kesehatan reproduksi. Jakarta : EGC; 2004.

9. Chandra A. Hubungan underlying factors dengan kejadian stunting pada anak 1-2 tahun. [Tesis] Semarang : Universitas Diponegoro; 2011.

10. Silaban, Jojor. Faktor Faktor Risiko Stunting pada Anak Pendidikan Anak Usia Dini di Kecamatan Parbuluan Kabupaten Dairi. [Tesis] Dairi : Akper Pem. Kab Dairi; 2015 
11. BAPPENAS. (2011). Rencana Aksi Nasional Pangan dan Gizi 20112015.http://www.4shared.com/get/ I45gBOZ/Rencana_Aksi_Nasional_Pangan . Diakses 10 November 2018

12. Astuti HW. Ilmu gizi dalam keperawatan. Cetakan Pertama edn, Jakarta : Trans Info Media; 2011. hlm. 83-84.

13. Affandi B. Buku panduan praktis pelayanan kesehatan maternal dan neonatus. Jakarta : Yayasan Bina Pustaka Sarwono Prawiro Hardjo; 2006.

14. Supariasa IDN, Bachyar B, Ibnu F. Penilaian status gizi. Jakarta: EGC; 2002. hlm 18-20, 28, 71, 34-35, 94-96, 114, 177, 181, 187-188

15. Nasikhah R, Ani M. Faktor risiko kejadian stunting pada balita usia 24-36 bulan di kecamatan Semarang Timur. [Tesis] Semarang : Journal of Nutrition College; 2012.

16. Marmi. Gizi dalam kesehatan reproduksi. Cetakan Pertama edn, Yogyakarta : Pustaka Belajar; 2013.

17. Arifin DZ, Irdasari SY, Sukandar H. Analisis sebaran dan faktor risiko stunting pada balita di Kabupaten Purwakarta 2012. [Tesis] Bandung : Fakultas Kedokteran Program Studi Magister Ilmu Kesehatan Masyarakat Universitas Padjajaran; 2012.

18. Rahayu LS, Sofyaningsih M. Pengaruh BBLR (berat badan lahir rendah) dan pemberian asi ekslusif terhadap perubahan status stunting pada balita di kota dan kabupaten tangerang provinsi Banten. [Tesis] Jakarta : Universitas Muhammadiyah Prof. Dr. HAMKA; 2011. 